\title{
The Paradigm Shift in Physiotherapy Care
}

\author{
Balbino Rivail Ventura Nepomuceno Júnior* \\ Master in Medicine and Health from the Federal University of Bahia, Reative Physiotherapy Specialist, Brazil
}

Submission: January 08, 2018; Published: January 19, 2018

*Corresponding author: Balbino Rivail V Nepomuceno Junior, Master in Medicine and Health from the Federal University of Bahia, Reative Physiotherapy Specialist, End: Av. Centenário, Ed. Empresarial Centenário, n 2411, sl 403, Chame-chame, Salvador-Bahia, Brazil, Email: balbino.nepomuceno@gmail.com

\section{Opinion}

Since its conception in the midst of World War II and outbreaks of disabling infectious contagious diseases such as Poliomyelitis, Physiotherapy has always had its identity linked to the rehabilitation of preexisting dysfunctions. The trajectory of the scientific evidence of physiotherapeutic techniques and resources also showed the path for tertiary care, focused on the return of lost functions, in the face of ongoing diseases and limitations. However, some researches following this ideal have not found significant results in the main clinical outcomes that change the prognosis of the assisted population, such as survival, morbidity, quality of life, health care costs, hospitalization length, length of mechanical ventilation (MV) or frequency of hospitalization.

In the last decade, the direction of the application of physiotherapeutic techniques and resources has shown a very promising paradigm shift. This change refers to the adoption of three basic principles of physical exercise prescription: periodicity; progression; reversibility. The stimulus must be employed more often than for therapeutic purposes, the exercise load would be individualized and progressive whenever possible and early institution should always occur, thus preventing the progression of functional limitations. Such a view is a feasible justification for the inclusion of some conducts, with limited scientific evidence, as standard treatment of pathologies and their main dysfunctions.

The mobilization of the critical patient out of the hospital bed, nowadays known as "early mobilization", is a clear example of this paradigm shift. Scweickert et al. [1] performed a clinical trial with early institution of mobilization and exercises of Physical Therapy and Occupational Therapy, which observed a lower functional loss compared to normal values in the intervention group ( $59 \%$ vs $35 \%$, $\mathrm{p}=0.02$ ), a longer period of days of MV free, and a lower rate of Delirium occurrence compared to standard care. Following the view of conducts instituted before the dysfunction, De Araújo et al. [2] used two daily applications of neuromuscular electrical stimulation (NMES) among patients with mechanical ventilation, even under sedation, obtaining an increase in functional capacity measured through the six-minute walk test (6MWT) when compared to a group control $(\mathrm{p}<0.001)$. Also applying NMES, Rousti et al. [3] have found higher levels of muscle strength measured by the MRC scale for skeletal muscle $(p=0.04)$. This study has also observed a statistically significant reduction in weaning time from MV and MV length in comparison with the control group.

Modification on non-invasive ventilation (NIV) also had its role in modified weaning; it is no longer being used as a rescue maneuver after the onset of symptoms of respiratory failure after extubation, but with indication of early use, as directed by the last American Thoracic Society guideline on weaning [4]. In this perspective, the NIV institution should be immediate after extubation in patients with risk factors delimiting a group of risk for post-extubation failure, such as chronic hypercapnic patients, cardiopaths, neuromuscular disorders and those exposed to prolonged MV [5,6].

Guérin et al. [7] showed the importance of the basic principles of periodicity and reversibility in a clinical trial on treatment of patients with Severe Acute Respiratory Distress Syndrome (ARDS) in which the prone positioning was early instituted at the onset of symptoms and maintained for 16 hours, with daily repeating of positioning until achieve $\mathrm{PaO} 2$ / FiO2 $>150 \mathrm{mmHg}$. This study observed a significantly decreased of the 28 -days $(16.0 \%$ vs $32.8 \%, \mathrm{p}<0.001)$ and 90 -days mortality (23.6\% vs $41.0, \mathrm{p}<0.001)$ in the intervention group compared with the control group. A posterior meta-analysis [8], confirms that early application of prone positioning and maintenance of this position for periods longer than 10 hours per day are related to reduction of mortality in severe ARDS.

In a recent study by our research group [9] we observed that the early institution of inspiratory muscle training in hospitalized 
patients with risk factors for prolonged hospitalization is a protective factor for hospitalization complications, such as muscle weakness ( $R R=0.36 ; 95 \%$ CI 0.19-0.98; $\mathrm{p}=0.02)$, endotracheal intubation ( $R R=0.36 ; 95 \%$ CI $0.27-0.97 ; p=0.03)$, and mortality ( $R R=0.23$; 95\% CI 0.2-0.94; $p=0.04$ ), besides being related to a shorter length of hospital stay $(35.3 \pm 2.7 \mathrm{vs}$. $41.8 \pm 3.5$ days, $\mathrm{p}<0.01$ ) compared to a placebo group.

\section{References}

1. Sckweickert WD, Pohlman MC, Pohlman AS, Nigos C, Pawlik AJ, et al. (2009) Early physical and occupational therapy in mechanically ventilated, critically ill patients: a randomised controlled trial Lancet 373(9678): 1874-1882.

2. De Araújo CJ, Gonçalves FS, Bittencourt HS, dos Santos NG, Mecca Junior SV, et al. (2012) Effects of neuromuscular electrostimulation in patients with heart failure admitted to ward. Journal of Cardiothoracic Surgery 15(7): 124

3. Routsi C, Gerovasili V, Vasileiadis I, Karatzanos E, Pitsolis T, et al. (2010) Electrical muscle stimulation prevents critical illness polyneuromyopathy: a randomized parallel intervention trial. Critical Care 14(2): R74.

4. Ouellette DR, Patel S, Girard TD, Morris PE, Schmidt GA, Truwit JD, et al. (2017) Liberation from mechanical ventilation in critically ill adults: an official american college of chest physicians/american thoracic society clinical practice guideline: inspiratory pressure augmentation during spontaneous breathing trials, protocols minimizing sedation, and noninvasive ventilation immediately after extubation. CHEST 151(1): 166-180.

5. Bajaj A, Rathor P, Sehgal V, Shetty A (2015) Eficacy of non invasive ventilation after planned extubation: a systematic review and metaanalysis of randomized controlled trials. Heart Lung 44(2): 150-157.

6. Oliveira FTO, Gardenghi G, Nepomuceno Júnior BRV (2017) Desmame ventilatório no paciente cardiopata grave. In: Martins JA, Reis LFF, Andrade FMD (Eds.), Associação Brasileira de Fisioterapia Cardiorrespiratória e Fisioterapia em Terapia Intensiva, organizadores. PROFISIO Programa de Atualização em Fisioterapia em Terapia Intensiva Adulto: Ciclo 8. Artmed Panamericana, Porto Alegre, Brazil, p. 9-53.

7. Guérin C, Reigner J, Richard JC, Beuret P, Gacouin A, et al. (2013) Prone positioning in severe acute respiratory distress syndrome. N Engl J Med 368(23): 2159-2168.

8. Lee JM, Bae W, Lee YJ, Cho YJ (2014) The efficacy and safety of prone positional ventilation in acute respiratory distress syndrome: updated study-level meta-analysis of 11 randomized controlled trials. Crit Care Med 42(5): 1252-1262.

9. Nepomuceno BRV, Barreto SM, Almeida NC, Guerreiro CF, Xavier Souza E, et al. (2017) Safety and efficacy of inspiratory muscle training for preventing adverse outcomes in patients at risk of prolonged hospitalisation. Trials 18: 626.

\section{Your next submission with Juniper Publishers will reach you the below assets}

- Quality Editorial service

- Swift Peer Review

- Reprints availability

- E-prints Service

- Manuscript Podcast for convenient understanding

- Global attainment for your research

- Manuscript accessibility in different formats

\section{( Pdf, E-pub, Full Text, Audio)}

- Unceasing customer service

Track the below URL for one-step submission

https://juniperpublishers.com/online-submission.php 